\title{
Pregnancy-associated malaria and malaria in infants: an old problem with present consequences
}

\author{
Violeta Moya-Alvarez ${ }^{1,2,3^{*}}$, Rosa Abellana ${ }^{4}$ and Michel $\operatorname{Cot}^{1,2}$
}

\begin{abstract}
Albeit pregnancy-associated malaria (PAM) poses a potential risk for over 125 million women each year, an accurate review assessing the impact on malaria in infants has yet to be conducted. In addition to an effect on low birth weight (LBW) and prematurity, PAM determines foetal exposure to Plasmodium falciparum in utero and is correlated to congenital malaria and early development of clinical episodes during infancy. This interaction plausibly results from an ongoing immune tolerance process to antigens in utero, however, a complete explanation of this immune process remains a question for further research, as does the precise role of protective maternal antibodies. Preventive interventions against PAM modify foetal exposure to P. falciparum in utero, and have thus an effect on perinatal malaria outcomes. Effective intermittent preventive treatment in pregnancy (IPTp) diminishes placental malaria (PM) and its subsequent malaria-associated morbidity. However, emerging resistance to sulphadoxine-pyrimethamine (SP) is currently hindering the efficacy of IPTp regimes and the efficacy of alternative strategies, such as intermittent screening and treatment (IST), has not been accurately evaluated in different transmission settings. Due to the increased risk of clinical malaria for offspring of malaria infected mothers, PAM preventive interventions should ideally start during the preconceptual period. Innovative research examining the effect of PAM on the neurocognitive development of the infant, as well as examining the potential influence of HLA-G polymorphisms on malaria symptoms, is urged to contribute to a better understanding of PAM and infant health.
\end{abstract}

Keywords: Pregnancy-associated malaria, Immune tolerance, Intermittent preventive treatment in pregnancy, Parasitaemia, Infancy, Sulphadoxine-pyrimethamine

\section{Background}

Pregnancy-associated malaria (PAM), defined as peripheral or placental infection by Plasmodium, presents as a major public health concern due to significant adverse health effects on both the mother and the foetus. Women are increasingly susceptible to malaria infection during pregnancy since Plasmodium falciparum, the most common parasite responsible for malaria, avoids spleen clearance through expression of proteins that bind to the chondroitin sulphate A (CSA) in the placental intervillous space [1-3]. Consequently, the foetus is initially exposed to

\footnotetext{
* Correspondence: vmoyaalvarez@gmail.com

${ }^{1}$ Institut de Recherche pour le Développement, UMR 216 Mère et enfant face aux infections tropicales, Faculté de Pharmacie Paris Descartes, 4 Avenue de I'Observatoire, 75270 Paris, France

${ }^{2}$ Université Pierre et Marie Curie (Paris 6), Centre Biomédical des Cordeliers,

15, rue de l'Ecole de Médecine, 75006 Paris, France

Full list of author information is available at the end of the article
}

malaria in utero. Epidemiological studies estimate 125 million pregnancies are at risk of malaria infection every year [4] within a purposed estimate of 32 million women who become pregnant every year in malaria endemic subSaharan Africa countries [5].

The effects of pregnancy-associated malaria on infants include stillbirth, congenital malaria, foetal anaemia, and low birth weight (LBW), caused by intra-uterine growth retardation (IUGR) and pre-term delivery [6-11]; considering the subsequent adverse health outcomes PAM related deaths would account for 75,000 to 200,000 infant deaths in sub-Saharan Africa [12].

Ultimately, pregnancy-associated malaria determines foetal exposure to P. falciparum in utero. Indeed, placental malaria is identified as a significant indicator for increased susceptibility to malaria during infancy [13-18]. In turn, 
PAM control strategies modify foetal exposure to $P$. falciparum in utero.

The prevalence of PAM is influenced by transmission, the immunity of the mother, and protective measures, such as insecticide-treated nets (ITNs) or intermittent preventive treatment in pregnancy (IPTp) [10]. Despite the considerable literature on PAM epidemiological and clinical outcomes, no clear conclusions regarding PAM's effect on malaria in infants have been accurately reported. Further well-known risk factors for malaria in infants include high transmission or HIV co-morbidity [19], but exploring PAM influence on malaria risk during infancy could significantly contribute to better understand Plasmodium infection among infants. This review aims to revisit the present evidence on pregnancy-related factors that influence malaria in infants, including the effect of control interventions and novel research perspectives. Results are presented by the following topic areas: the epidemiological evidence on the effect of PAM on malaria in the offspring, the risk factors determining exposure to Plasmodium in utero, with special regard to control interventions, such as IPTp and ITNs, and the influence of the increasing resistance to SP-IPTp on malaria perinatal outcomes. Finally, new research perspectives to examine the effect of PAM on infant health are discussed.

\section{Methods: search strategy and selection criteria}

A systematic literature specifying the epidemiology of malaria in infants with a focus on malaria risk factors in infants, was realized between the 10th January 2012 and the 9th June 2014 utilizing PubMed, the Cochrane Library, Global Health and World Health Organization regional databases. In total, 1,136 articles in English, French, Spanish and Portuguese were classified for review. A combination of standardized terms were used as search criteria; concerning PubMed, the search terms utilized were the Medical Subjects Headings (MeSH) "Parasitaemia" OR "Malaria" OR "Anaemia”. In addition, complementary articles, reports, and studies were identified through review and citations. Search criteria for relevant PAM and IPTp studies accepted all designs with the sole caveat that they originated from a malaria endemic country. Three-hundred and fifty-five articles were selected for final review. Due to the limited number of studies and reviews, no sensitivity analysis was realized. No date restrictions were applied and publication bias was not addressed.

\section{Pregnancy-associated malaria and malaria in infants: epidemiological evidence}

Pregnancy-associated malaria is consistently associated with an increased malaria risk during infancy [13-16,18] and has been associated with congenital malaria, increased malaria episodes, anaemia, and non-malaria fever episodes in infants $[10,20]$. The principal findings of several reviewed studies are presented in Table 1.

Congenital malaria, defined as the presence of asexual $P$. falciparum parasites in the cord blood or in the peripheral blood during the first week of life [25], is the result of transplacental transmission of parasites just before or during delivery. Congenital malaria rates range between 0.83 and 5.96\% [17,25-29] in recent epidemiological studies. The introduction of molecular techniques has increased the detection of cord blood parasitaemia raising prevalence rates to 33\% [30]. Congenital malaria might entail clinically relevant symptoms in some cases, such as high fever and convulsions, anaemia, hepatosplenomegaly, jaundice, anorexia, vomiting, diarrhoea, drowsiness, pallor, respiratory distress, and cyanosis [30,31]. Although congenital malaria is an important factor in the differential diagnostic of neonatal fever in endemic countries, severe symptoms are rare and, hence, it does not appear to constitute an epidemic at present.

PAM is also associated with earlier episodes, as well as overall clinical malaria episodes, in infants [13-15,17,23]. In a landmark longitudinal cohort study of infants in Cameroon, placental P. falciparum infection was associated with infant malaria between four and six months, and parasitaemia rates were higher between five to eight months in offspring of placenta-infected mothers compared to offspring of mothers without placental infection independently of congenital infection [13] (at 6 months: PM+: 36\%; PM-: 14\%, p <0.05). A study in Tanzania found an interaction between gravidity and placental malaria. The findings demonstrated that the offspring of multigravid women with placental malaria had the highest odds of subsequent malaria episodes (Adjusted Odds Ratio $(\mathrm{AOR}=1.59)$ 95\% confidence interval (CI) 1.162.17) [14], and the lowest odds were attributed to offspring of primigravid placenta infected mothers.

Regarding the early appearance of parasites in infants, the above mentioned study in Tanzania reported a 1.41 estimated hazard ratio (HR) (95\% CI 1.01-1.99) of first parasitaemia for offspring of mothers with $P$. falciparum placental infection after adjusting for gravidity, transmission season at time of birth, area of residence, and bed net usage [14]. In Gabon, a significant correlation between placental malaria and the first malaria episode was also found (adjusted HR (AHR) $=2.1$; 95\% CI 1.23.7) after adjustment for gravidity, season of birth, area of residence, IPTp versus placebo, and ITNs [15]. A more recent study in Mozambique found that infants born to women who had clinical malaria during pregnancy, or acute placental infection, had an increased risk of clinical malaria during infancy $(\mathrm{OR}=1.96 ; 95 \% \mathrm{CI}$, $1.13-3.41$, and $\mathrm{OR}=4.63 ; 95 \%$ CI 2.10-10.24, respectively) [22]. Furthermore, a cohort study conducted in Tori Bossito (Benin) confirmed the link between PM 
Table 1 Influence of maternal parasitemia on malaria in infants

\begin{tabular}{|c|c|c|c|c|c|c|c|c|c|c|c|c|}
\hline Cohort & $\begin{array}{l}\text { Study } \\
\text { design and } \\
\text { simple size }\end{array}$ & $\begin{array}{l}\text { Time } \\
\text { period }\end{array}$ & $\begin{array}{l}\text { Transmission } \\
\text { setting }\end{array}$ & $\begin{array}{l}\text { Malaria } \\
\text { prevention } \\
\text { strategy } \\
\text { during } \\
\text { pregnancy } \\
\end{array}$ & $\begin{array}{l}\text { Treatment } \\
\text { drug } \\
\text { regime }\end{array}$ & $\begin{array}{l}\text { Proportion of } \\
\text { maternal } \\
\text { peripheral } \\
\text { parasitemia at } \\
\text { delivery }\end{array}$ & $\begin{array}{l}\text { Proportion of } \\
\text { placental } \\
\text { parasitemia }\end{array}$ & $\begin{array}{l}\text { Proportion of } \\
\text { neonatal } \\
\text { parasitemia }\end{array}$ & $\begin{array}{l}\text { Infant } \\
\text { follow- } \\
\text { up } \\
\text { period }\end{array}$ & $\begin{array}{l}\text { Median time } \\
\text { to first } \\
\text { parasitemia } \\
\text { (days, min, } \\
\text { max) }\end{array}$ & $\begin{array}{l}\text { Association of } \\
\text { infant malaria } \\
\text { with PAM }\end{array}$ & $\begin{array}{l}\text { Early infant } \\
\text { parasitemia } \\
<3 \text { months }\end{array}$ \\
\hline $\begin{array}{l}\text { Mangochi } \\
\text { [21] (Malawi) }\end{array}$ & $\begin{array}{l}\text { Clinical trial on } \\
\text { comparative } \\
\text { efficacy of CQ } \\
\text { or MQ; infant } \\
\text { cohort follow- } \\
\text { up (1766 } \\
\text { women at } \\
\text { delivery and } \\
1289 \text { infants) }\end{array}$ & 1988-1990 & $\begin{array}{l}\text { Perennial with } \\
\text { seasonal peaks }\end{array}$ & $\mathrm{CQ}$ and $\mathrm{MQ}$ & CQ & $\begin{array}{l}\text { CQ: } 20.3 \% \\
\text { MQ: } 4.1 \%\end{array}$ & $\begin{array}{l}\text { CQ: } 25.1 \% \\
\text { MQ: } 6.2 \%\end{array}$ & $\begin{array}{l}\text { CQ: } 8.6 \% \\
\text { MQ: } 3.1 \%\end{array}$ & $\begin{array}{l}12 \\
\text { months }\end{array}$ & 199 (192-207) & $\begin{array}{l}\text { at } 3 \text { months: } 1.1 \\
(0.7-1.9)\end{array}$ & $18.5 \%$ \\
\hline $\begin{array}{l}\text { Ebolowa [13] } \\
\text { (Cameroon) }\end{array}$ & $\begin{array}{l}\text { Infant cohort } \\
\text { follow-up } \\
\text { (197) }\end{array}$ & 1993-1995 & $\begin{array}{l}\text { Perennial with } \\
\text { seasonal peaks }\end{array}$ & CQ & CQ & & $\begin{array}{l}22.84 \% \\
\text { (Primigravid: } \\
69 \% ; \\
\text { Multigravid: } \\
\text { 31\%) }\end{array}$ & & $\begin{array}{l}24 \\
\text { months }\end{array}$ & $\begin{array}{l}\text { PM+: } 217 \\
\text { PM-:350 }\end{array}$ & $\begin{array}{l}\text { at } 6 \text { months: } \\
\text { PM+: } 36 \% \text {; PM-: } \\
14 \%, p<0.05 \text { at } 2 \\
\text { years: PM+: } \\
46.5 \% \text {; PM-: } \\
38.5 \%, p=0.6\end{array}$ & $\approx 12 \%$ \\
\hline $\begin{array}{l}\text { Muheza [14] } \\
\text { (Tanzania) }\end{array}$ & $\begin{array}{l}\text { Infant cohort } \\
\text { follow-up } \\
\text { (453) }\end{array}$ & $2002-2004$ & $\begin{array}{l}\text { Perennial with } \\
\text { seasonal peaks } \\
\text { (400 infective } \\
\text { mosquito } \\
\text { bites each } \\
\text { year) }\end{array}$ & $\begin{array}{l}\text { SP (area } \\
\text { with 68\% } \\
\text { resistance } \\
\text { 14-day } \\
\text { treatment } \\
\text { failure rate) }\end{array}$ & & & $\begin{array}{l}15.2 \% \\
\text { (Primigravid } \leq 2: \\
24 \% ; \\
\text { Multigravid >2: } \\
5.6 \% \text { ) }\end{array}$ & & $\begin{array}{l}12 \\
\text { months }\end{array}$ & $\begin{array}{l}266(238-294) \\
\text { PM-:273 (245- } \\
322) \text { PM+: } 244 \\
(147-266) ;\end{array}$ & $\begin{array}{l}\text { Primigravidae: } \\
\text { PM+:AOR= } \\
0.21,(0.09-0.47) \\
\text { PM-: Refer } \\
\text { ence*** Multi } \\
\text { gravidae: PM+: } \\
\text { AOR =1.59, } \\
(1.16-2.17) \\
\text { PM-:AOR=0.67, } \\
(0.50-0.91)\end{array}$ & $\begin{array}{l}\mathrm{PM}+\approx 20 \% \\
\mathrm{PM}=10 \%\end{array}$ \\
\hline $\begin{array}{l}\text { Lambarené } \\
\text { [15] (Gabon) }\end{array}$ & $\begin{array}{l}\text { Infant cohort } \\
\text { follow-up } \\
\text { (527) }\end{array}$ & $2002-2004$ & Perennial & No & & $10.5 \% *$ & $9.48 \%$ & & $\begin{array}{l}30 \\
\text { months }\end{array}$ & $\begin{array}{l}\text { Primigravidae: } \\
\text { PM+:107 (83- } \\
\text { 139) PM-:102 } \\
\text { (29-205) Multi- } \\
\text { gravidae: PM } \\
\text { +:111 (13-189) } \\
\text { PM-:92 (27- } \\
\text { 208) }\end{array}$ & $\begin{array}{l}\text { PM+:AOR= 2.1, } \\
(1.2-3) \\
\text { PM-: Reference** }\end{array}$ & $\begin{array}{l}\mathrm{PM}+\approx 2 \% \\
\mathrm{PM}-\approx 0 \%\end{array}$ \\
\hline $\begin{array}{l}\text { Manhiça [22] } \\
\text { (Mozambique) }\end{array}$ & $\begin{array}{l}\text { Clinical trial on } \\
\text { the efficacy of } \\
\text { SP compared } \\
\text { to placebo; } \\
\text { infant cohort } \\
\text { follow-up } \\
\text { (1030 women } \\
\text { at delivery and } \\
997 \text { infants) }\end{array}$ & $2003-2005$ & $\begin{array}{l}\text { Perennial with } \\
\text { seasonal peaks }\end{array}$ & $\begin{array}{l}\text { ITNs vs } \\
\text { ITNs+SP }\end{array}$ & SP-AQ & $\begin{array}{l}\text { ITNs+ } \\
\text { placebo:15.15\% } \\
\text { ITNs+SP: } 7.1 \%\end{array}$ & $\begin{array}{l}\text { ITNs+ } \\
\text { placebo:52.27\% } \\
\text { ITNs+SP: } \\
52.11 \%\end{array}$ & $\begin{array}{l}\text { ITNs+ } \\
\text { placebo:1.15\% } \\
\text { ITNs+SP: } \\
0.92 \%\end{array}$ & $\begin{array}{l}12 \\
\text { months }\end{array}$ & & $\begin{array}{l}\text { Clinical PAM: } \\
\text { AOR=1.96 (1.13- } \\
\text { 3.41) Acute PM: } \\
\text { AOR= 4.63 (2.1- } \\
\text { 10.24) Chronic } \\
\text { PM: AOR=3.95 } \\
\text { (2.07-7.55) } \\
\text { PM-: Reference }\end{array}$ & \\
\hline
\end{tabular}


Table 1 Influence of maternal parasitemia on malaria in infants (Continued)

\begin{tabular}{|c|c|c|c|c|c|c|c|c|c|c|c|}
\hline $\begin{array}{l}\text { Tori Bossito } \\
{[17,23] \text { (Benin) }}\end{array}$ & $\begin{array}{l}\text { Infant cohort } \\
\text { follow-up } \\
\text { (550) }\end{array}$ & $2007-2008$ & $\begin{array}{l}\text { Perennial with } \\
\text { seasonal peaks } \\
(400 \text { infective } \\
\text { mosquito } \\
\text { bites each } \\
\text { year) }\end{array}$ & $\mathrm{SP}$ & $\mathrm{AL}$ & $11 \%$ & $0.83 \%$ & $\begin{array}{l}12 \\
\text { months }\end{array}$ & $\begin{array}{l}\text { PM+: } 34 \\
\text { (4-83); PM-: } \\
43(4-85)\end{array}$ & $\begin{array}{l}\text { ITN:AOR=2.13 } \\
(1.24-3.67) \mathrm{No} \\
\text { ITN: AOR=1.18 } \\
(0.60-2.33)\end{array}$ & $20.3 \%$ \\
\hline $\begin{array}{l}\text { Mono [24] } \\
\text { (Benin) }\end{array}$ & $\begin{array}{l}\text { Mother and } \\
\text { infant cohort } \\
\text { follow-up } \\
\text { (218) }\end{array}$ & $2008-2010$ & $\begin{array}{l}\text { Mesoendemic } \\
\text { (1-35 bites/ } \\
\text { person/year) }\end{array}$ & SP & $\begin{array}{l}\text { Quinine or } \\
\text { SP }\end{array}$ & $3.67 \%$ & & $\begin{array}{l}12 \\
\text { months }\end{array}$ & $\begin{array}{l}\text { PAM+: } 362 \\
\text { (18-390) PAM-: } \\
365 \text { (64-449) }\end{array}$ & $\begin{array}{l}\text { PAM during the } \\
\text { 3rd trimester of } \\
\text { pregnancy: } \\
\text { AOR }=4.6 \text { (1.7; } \\
\text { 12.5) PAM } \\
\text { during the 1st } \\
\text { and 2nd } \\
\text { trimesters non } \\
\text { significant }\end{array}$ & \\
\hline
\end{tabular}

*data from a reference article.

**the association between placental malaria and malaria in the child was only statistically significant for children who were randomized to receive the sulphadoxine-pyrimethamine intervention (AHR=3 (1.5-6)).

***Analysis of the effect of IPTp on parasitemia of the offspring was performed for 882 women of this cohort. Among them, $21.6 \%$ received no IPTp, $42 \%$ one dose, and $36.4 \%$ two or more doses. 
and malaria in infants through consistent entomologic and environmental follow-up [17,23]. The study findings on infants sleeping in a house with an ITN confirmed the link between PM and malaria controlled for transmission intensity, seasonality, number of anopheles, antenatal care (ANC) visits, and maternal severe anaemia $(\mathrm{AHR}=2.13$; 95\% CI 1.24-3.67) compared with infants whose mothers did not have placental malaria at delivery. This cohort study additionally reports an increased susceptibility of infants to $P$. falciparum parasites with antigens to which they were previously exposed in utero suggesting an immune tolerance process undergoing during pregnancy [32]. PAM has also been associated with a reduction in maternal antibody transfer to the foetus [33,34], hence increasing infant susceptibility to parasites $[35,36]$. Consistent with the notion that the type, timing, and the duration of exposure to the parasite in utero determine susceptibility to malaria, infections occurring during the third trimester are associated with increased risk of infection and clinical malaria during the first year of life according to another study in the province of Mono (South Benin) [24].

Nevertheless, the effect of PAM on infant health may involve an overall increased morbidity and mortality. Placental malaria was additionally correlated with nonmalaria infections in the Tori Bossito cohort infants during the first 18 months of life suggesting that immune tolerance could also imply immunity in a more general manner besides malaria specific immunity [20]. Moreover, placental malaria posed a significant risk factor for overall mortality during the first year of life [37] in a study in Malawi, and another study from Mozambique [22] identified both acute placental malaria and cord blood parasitaemia with increased infant mortality. More precisely, in this study from Mozambique infant mortality was also significantly associated with malaria infection of the placenta (p-value $<0.012$ ) after adjustment on HIV status, LBW, maternal clinical malaria during pregnancy, foetal anaemia and IPTp regime. The risk of dying during infancy was increased among infants born to women with acute placental infection (OR $=5.08$; $95 \%$ CI 1.77-14.53), as well as among infants with parasitaemia in the cord blood $(\mathrm{OR}=19.31 ; 95 \% \mathrm{CI}, 4.44-$ 84.02).

A possible explanation for different immune tolerance effects of PAM relates to HLA-G polymorphisms and their association with different malaria susceptibility [38]. HIV infection influences as well a woman's susceptibility to malaria, and this is of major concern as both diseases overlap considerably in sub-Saharan Africa. Consistent evidence suggests both infections interact synergistically and result in poorer health outcomes [39]. PAM is more frequent among HIV infected women in comparison to non-infected women, and can increase maternal HIV load [40-42]. PAM in HIV-positive pregnant women is further associated with higher risk of both anaemia and LBW [40,43-45]. This results in overall increased maternal and infant mortality $[46,47]$.

A potential long-term consequence of PAM concerns neuro-cognitive impairment of infants exposed to malaria in utero. Due to recent evidence concerning the role of the complement system in the regulation of neurodevelopment, it has been proposed that excessive complement activation induced by placental malaria may disrupt normal neurodevelopment resulting in neurocognitive impairment of infants exposed to Plasmodium in utero [48].

Although a complete explanation of the physiopathology of PAM has not yet been understood, in utero exposure to malaria is probably nonetheless correlated with placental sequestration of erythrocytes. The immune tolerance process would plausibly then depend on the type of malaria antigen in contact with the foetus, the amount and the duration of the exposure, and the timing of exposure during pregnancy $[16,49]$. The interaction between gestation and infection timing during pregnancy has been previously shown to influence the pathologic consequences for the offspring. Due to the particular physiopathology of PAM, a specific immunity develops during the first pregnancy [10] and, hence, primigravidae are at higher risk of PAM compared to multigravidae [10]. In this respect, infants of primigravid women are also at higher risk of subsequent malaria in comparison to infants of multigravid women, mainly as a result of reduced antibody transfer [11]. Finally the timing of malaria episodes during pregnancy results in different effects on both the mother and the foetus; parasitaemia appears to be higher during the first and second trimesters, even if follow-up on $P$. falciparum parasitaemia during the first trimester has seldom been complete [10,50-53]. Essentially, the administration of IPTp at different moments determines different protection patterns for the infant [50] and, in parallel, a significant reduction in placental malaria and maternal parasitaemia has been extensively described [54] following the implementation of PAM control interventions. As a result of the different infant malaria outcomes depending on PAM and IPTp, and considering the body of the available research, the following questions are posed: How does exposure in utero to $P$. falciparum influence malaria in infants? How do control interventions modify in turn the impact of PAM on clinical malaria in infants?

\section{Pregnancy associated malaria and control interventions: effect on perinatal malaria outcomes}

Foetal exposure to Plasmodium in utero primarily depends on transmission and control interventions. 
Preventive measures substantially alter the interaction between exposure and immunity. IPT is a widespread preventive strategy to fight malaria and involves the administration of a curative dose of an effective antimalarial drug, regardless of the presence of Plasmodium in the blood, to prevent the disease [19]. IPT measures decrease parasitaemia, and consequently influence the immunity response of the infant to Plasmodium in utero through maternal intermittent preventive treatment in pregnancy (IPTp). Therefore, WHO recommends IPTp with SP for all pregnant women as early as possible in the second trimester, and at each scheduled antenatal care visit at least one month apart in areas of moderate to high malaria transmission [55], IPTp strategies are however not yet completely deployed in malaria endemic regions and the implementation of IPTp interventions interfere with PAM outcomes. Figure 1 presents the main characteristics concerning implementation of IPTp programmes in Africa.

Effective administration of IPTp clears placental parasitaemia and consequently modifies the exposure to malaria antigens resulting in a significant reduction in placental malaria and maternal parasitaemia [54]. Compared to case management or placebo in pregnant women, a two-dose IPTp regime with sulphadoxine-pyrimethamine (SP) significantly reduced placental malaria according to a review on four studies (relative risk $(R R)=0.48$ ) [56]. In a randomized, double blind, placebo-controlled trial with joint use of ITNs in Mozambique, SP-IPTp (1-2 doses) was correlated to a significant decrease only in active placental malaria [57] (Table 1). In Mali, placental parasitaemia was significantly reduced by SP-IPTp $($ AOR $=0.69)$ when compared to weekly administered chloroquine (CQ) [58] and confirmed higher SP efficacy compared to CQ already reported in Malawi [59]. A recent meta-analysis has concluded significant reduction in PM after three doses of SP compared to two doses [54], which corresponds to current WHO recommendations.

A comprehensive review encompassing published studies conducted between 1985 and 2000 found a PAM prevalence range of $10 \%$ to $65 \%$ among all gravidae [12], with a median prevalence of $27.8 \%$ [10]. In low-transmission African settings, the median prevalence peripheral infection was $13.7 \%$ and the placental malaria median prevalence was $6.7 \%$ [10]. Recent studies however reported a significant decline in prevalence following PAM control interventions. The protection of joint ITNs with IPTp-SP use is significant in only certain trials, yet reported ITN use ranges from 5 to $25 \%$, and this might not be sufficient enough to show an effect [60]. An article reviewed the influence of preventive measures on PAM during a decade, effectively 2002 to 2012, and reported placental malaria rates ranging from 2 to $29 \%$ among women treated with less than three doses (mainly two) of sulphadoxine- pyrimethamine (SP) compared to 2 to $8 \%$ among women receiving more than or equal three doses (mainly three) [60]. A novel study included within the afore mentioned review describes a two-fold lower prevalence of placental malaria in the three-dose SP group compared to the twodose SP group (adjusted prevalence ratio $=0.48$ ) [61]. Even if the augmented efficacy associated with higher doses is predominately observed in clinical trials rather than in studies of public health programme implementations [60], the emergence of SP resistance is certainly shaping the efficacy of IPTp, and consequently its influence on the malaria burden in infants.

\section{IPTp and malaria in infants: when protection encounters resistance}

Reduced compliance with drug regimes and the increasing resistance to anti-malaria drugs highlight the complexity of IPTp management at present. A 2007 metaanalysis confirmed that SP IPTp continued to benefit pregnant women in areas of up to $39 \%$ resistance to SP, measured by in vivo resistance at day 14 of treatment in children [56]. Similar results were found in Benin, where rates of in vivo resistance to SP were estimated to be $50 \%$ by day 28 of treatment in infants, and yet SP IPTp succeeded to prevent LBW [62]. However, studies published more recently display contradictory results. A study in Malawi, where there is a strong fixation of the resistant quintuple mutant, shows significantly reduced small for gestational age (SGA) rates in offspring of primigravid women having received $\geq 2$ doses of SP compared to 0-1 doses [63]. On the other hand, peripheral parasitaemia was is significantly higher among women having received $\geq 2$ doses of SP. Indeed, the effects of resistance on malaria clinical outcomes become more frequent in more recent studies from East Africa. In a Tanzanian site with high SP resistance (14-day parasitologic SP treatment failure rate in children of $68 \%$ ), IPTp was not associated with a reduction in odds of PM, LBW or maternal anaemia. Furthermore, it was associated with increased odds of foetal anaemia and severe malaria among the offspring $(\mathrm{AOR}=2.31)$ [64]. IPTp in this setting was associated with an overall increased risk of severe malaria $[64,65]$.

However a recent longitudinal study revealed no significant increase of malaria at delivery after IPTp treatment, albeit the increasing prevalence and fixation of SP-resistant $P$. falciparum haplotypes in another area in Malawi [66]. Evidence for the present efficacy of SPIPTp regimes is inconclusive but resistance to SP is spreading. Close monitoring of its efficacy is therefore necessary to determine if or when the treatment failure of SP-IPTp detected by some recent studies has become generalized at the population level, thus necessitating a switch to alternative drug regimes. Nevertheless, the 


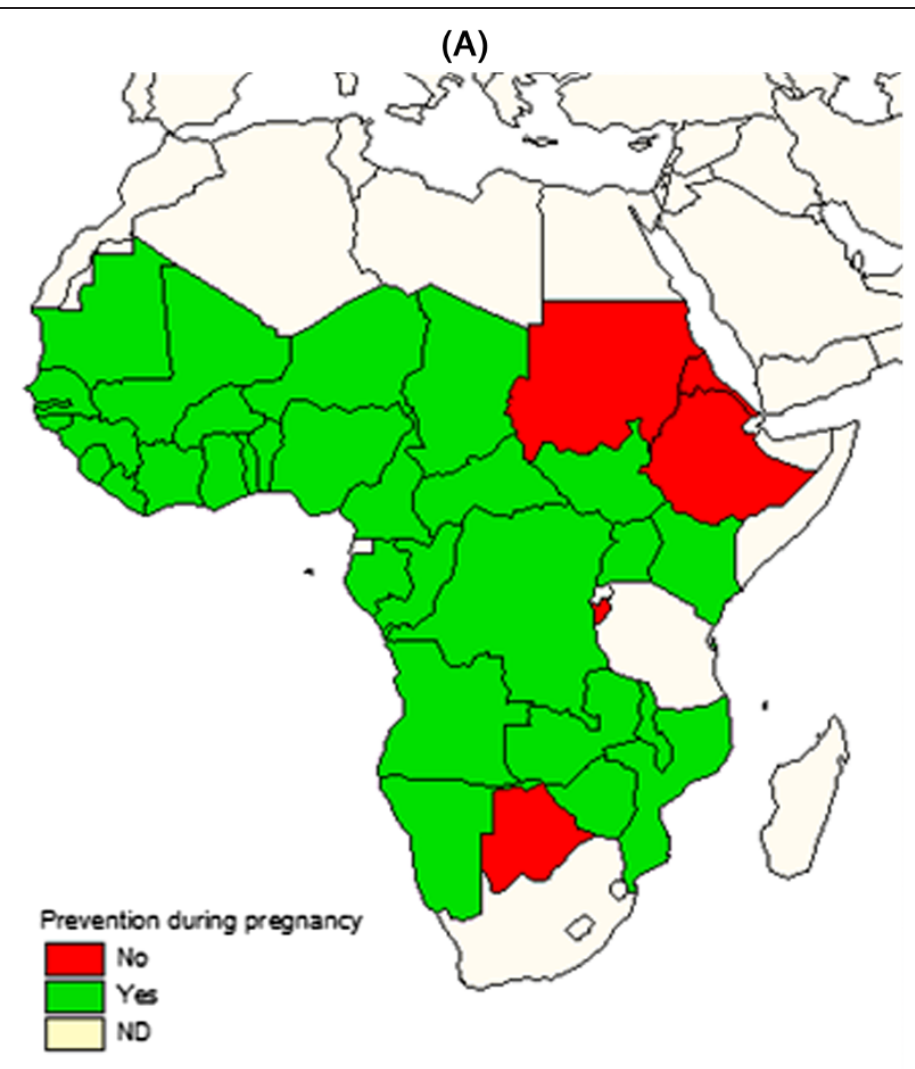

(B)

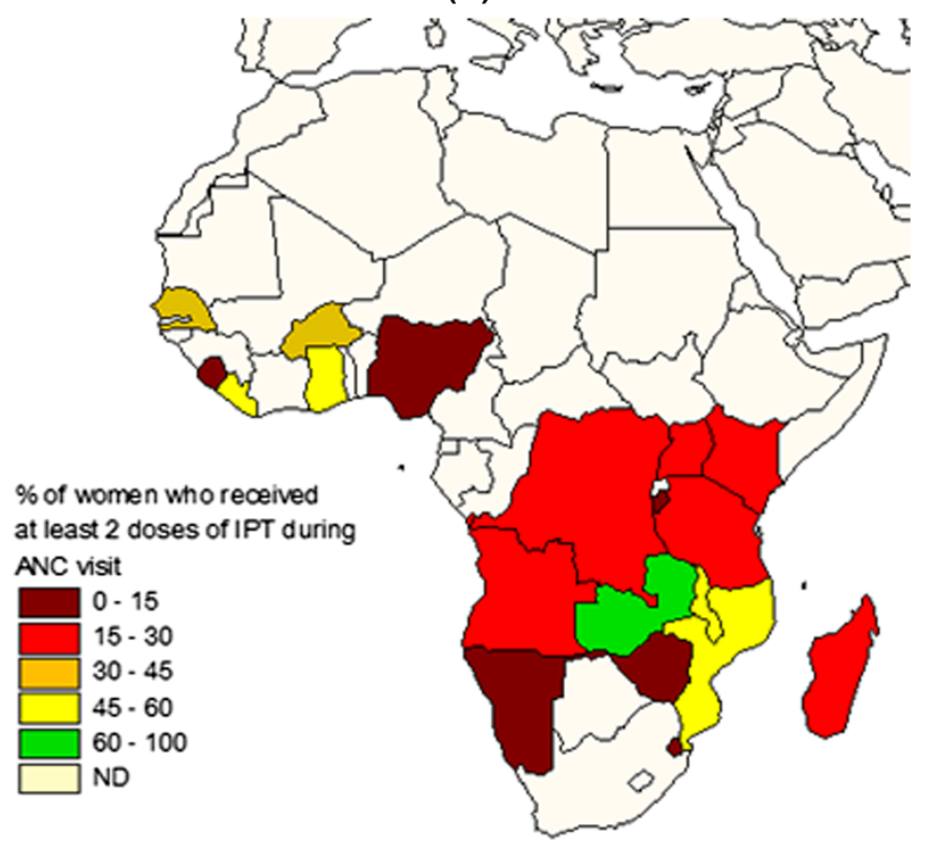

Source: WHO World Malaria Report 2013

Figure 1 Intermittent Preventive Treatment in pregnancy in Africa. Source: World Malaria report 2013. WHO publications 2013. A. Implementation of intermittent preventive treatment in pregnancy in Africa. B. The percentages of women having received at least 2 doses of IPTp are approximated data issue of the latest demographic surveys of the countries represented. 
Malaria Policy Advisory Committee (MPAC) cited a current paucity of data in order to determine the precise level of resistance obliging interruption of IPTp-SP treatment, especially in the absence of an established and effective alternative [55].

Currently, the Intermittent Screening and Treatment (IST) is a proposed alternative to IPTp in areas with substantial resistance against IPTp regimes. IST consists in screening for malaria infection using a malaria rapid diagnostic test (RDT) at scheduled antenatal clinic visits and subsequently treating positive women with an effective anti-malarial drug [67]. However, extensive evidence on IST efficacy is lacking in African regions and further efficacy studies should be conducted in broader geographical regions [68].

In summary, PAM determines foetal exposure to $P$. falciparum in utero and is hence correlated to congenital malaria and earlier development of clinical episodes in infancy, possibly as the consequence of an immune tolerance process in utero. Effective IPTp diminishes PM and malaria associated morbidity such as LBW, preterm delivery, IUGR, and perinatal mortality in areas where resistance to SP is not highly significant. Yet the influence of different IPTp regimes on malaria morbidity in infants remains a question for further research. The concrete effect of resistance and the ongoing immune tolerance process in utero have not been presently explored. Further evidence is also lacking on the importance of the timing of infection during pregnancy and infant malaria morbidity. There exists some evidence that earlier administration of IPTp has a positive effect on birth outcomes like LBW, nevertheless, later dosing provides a more continuous protection [50], thus necessitating the administration of three doses instead of two for improved clinical outcomes. In addition, the implementation of different IPTp regimes should be adapted according to transmission and the SP-resistance pattern. For example, IST has been applied successfully in an area of moderately high malaria transmission in Ghana [67]. IST should be further explored and its efficacy should be evaluated in other transmission settings to ascertain its utility as an effective tool for the control of PAM.

\section{Conclusions}

This review on the impact of PAM on malaria in infants substantiates the complexity of the subject and the necessity of a holistic approach for fighting malaria. In addition, research gaps should be fulfilled to enhance malaria outcomes. Strategies should start during the pre-conceptual period or at least during pregnancy, as there is evidence of increased infant susceptibility to parasites carrying antigens to which they were previously exposed while in utero. A complete explanation of the immune process remains a question for further research as well as the precise effect of the timing of in utero exposure to the parasite. Furthermore, the role of protective maternal antibodies has not yet been clarified. Operational research on different preventive IPT strategies should also be continuously conducted, and cost effectiveness analysis for community-level IST interventions should be investigated.

Finally, novel aspects of research on PAM should be further explored. Due to the long-term impact of placental malaria's possible neuro-cognitive consequences, the scientific community should prioritize studies investigating this interaction. An exploration of the influence of HLA-G polymorphisms on subsequent malaria symptoms would serve as well as an important contribution for infant malaria risk factors.

\section{Abbreviations}

ACT: Artemisinin-based combination therapy; AHR: Adjusted hazard ratio; AL: Artemether-lumefantrine; ANC: Antenatal care; AOR: Adjusted odds ratio; AQ: Amodiaquine; CQ: Chloroquine; HR: Hazard ratio; IPTp: Intermittent preventive treatment in pregnancy; IST: Intermittent Screening and Treatment; ITNs: Insecticide-treated nets; IUGR: Intra-uterine growth retardation; LBW: Low birth weight; MeSH: Medical Subjects Headings; MPAC: Malaria Policy Advisory Committee; MQ: Mefloquine; OR: Odds ratio; PAM: Pregnancy associated malaria; PM: Placental malaria; RDT: Rapid diagnostic test; RR: Relative risk; SGA: Small for gestational age; SP: Sulphadoxine-pyrimethamine; SPR: Slide positivity rate.

\section{Competing interests}

The authors declare that they have no competing interests.

\section{Authors' contributions}

VMA gathered and selected the articles, realized the article database and drafted the manuscript. RA realized the figure and helped to draft the manuscript. MC participated in the design and coordination of the article and helped to draft the manuscript. All authors read and approved the final manuscript.

\section{Acknowledgements}

Jessica Barry read and edited the manuscript making valuable linguistic corrections. Philippe Deloron and Adrian Luty made valuable contributions to the intellectual content of the article. José Juan Lopez-Rubio, Isabel Puigdomènech and Laura Gomez-Valero contributed materials essential for the study. Violeta Moya-Alvarez is funded by the Doctoral Network of the Ecole des Hautes Etudes en Santé Publique and the Direction Générale de I'Armement. Rosa Abellana is funded by the Universitat de Barcelona. Michel Cot is funded by the Institut de Recherche pour le Développement and the Université Pierre et Marie Curie.

\section{Author details}

${ }^{1}$ Institut de Recherche pour le Développement, UMR 216 Mère et enfant face aux infections tropicales, Faculté de Pharmacie Paris Descartes, 4 Avenue de I'Observatoire, 75270 Paris, France. ${ }^{2}$ Université Pierre et Marie Curie (Paris 6), Centre Biomédical des Cordeliers, 15, rue de l'Ecole de Médecine, 75006 Paris, France. ${ }^{3}$ Réseau doctoral de l'Ecole des Hautes Etudes en Santé Publique, Avenue du Professeur Léon-Bernard, CS 74312-35043 Rennes, France. ${ }^{4}$ Departament de Salut Pública, Facultat de Medicina, Casanova 143, 08036 Barcelona, Spain.

Received: 22 March 2014 Accepted: 26 June 2014 Published: 11 July 2014

\section{References}

1. David PH, Hommel M, Miller LH, Udeinya IJ, Oligino LD: Parasite sequestration in Plasmodium falciparum malaria: spleen and antibody modulation of cytoadherence of infected erythrocytes. Proc Natl Acad Sci US A 1983, 80:5075-5079. 
2. Fried M, Duffy PE: Adherence of Plasmodium falciparum to chondroitin sulfate A in the human placenta. Science 1996, 272:1502-1504.

3. Salanti A, Staalsoe T, Lavstsen T, Jensen ATR, Sowa MPK, Arnot DE, Hviid L, Theander TG: Selective upregulation of a single distinctly structured var gene in chondroitin sulphate A-adhering Plasmodium falciparum involved in pregnancy-associated malaria. Mol Microbiol 2003, 49:179-191.

4. Dellicour S, Tatem AJ, Guerra CA, Snow RW, ter Kuile FO: Quantifying the number of pregnancies at risk of malaria in 2007: a demographic study. PLoS Med 2010, 7:e1000221.

5. WHO: World Malaria Report. Geneva: World Health Organization; 2012.

6. Brabin BJ: The Risk and Severity of Malaria in Pregnant Women. Geneva: World Health Organisation publications; 1991:1-67.

7. Menendez C: Malaria during pregnancy : a priority area of malaria research and control. Parasitol Today 1995, 11:178-183.

8. Nosten F, Rogerson SJ, Beeson JG, Mcgready R, Mutabingwa TK, Brabin B: Malaria in pregnancy and the endemicity spectrum: what can we learn? Trends Parasitol 2004, 20:425-432.

9. Brabin BJ, Romagosa C, Abdelgalil S, Menéndez C, Verhoeff FH, McGready R, Fletcher KA, Owens S, D'Alessandro U, Nosten F, Fischer PR, Ordi J: The sick placenta-the role of malaria. Placenta 2004, 25:359-378.

10. Desai M, Kuile FO, Nosten F, Mcgready R, Asamoa K, Brabin B, Newman RD: Epidemiology and burden of malaria in pregnancy. Lancet Infect Dis 2007, 7(2)(February):93-104.

11. Rogerson SJ, Hviid L, Duff PE, Leke RFG, Taylor DW: Malaria in pregnancy: pathogenesis and immunity. Lancet Infect Dis 2007, 7:105-117.

12. Steketee RW, Nahlen BL, Parise ME, Menendez C: The burden of malaria in pregnancy in malaria-endemic areas. Am J Trop Med Hyg 2001, 64(1-2 Suppl):28-35.

13. Le Hesran J-Y, Cot M, Personne P, Fievet N, Dubois B, Beyeme M, Boudin C, Deloron P: Maternal placental infection with Plasmodium falciparum and malaria morbidity during the first 2 years of life. Am J Epidemiol 1997, 146:826-831.

14. Mutabingwa TK, Bolla MC, Li J-L, Domingo GJ, Li X, Fried M, Duffy PE: Maternal malaria and gravidity interact to modify infant susceptibility to malaria. PLoS Med 2005, 2:e407.

15. Schwarz NG, Adegnika AA, Breitling LP, Gabor J, Agnandji ST, Newman RD, Lell B, Issifou S, Yazdanbakhsh M, Luty AJF, Kremsner PG, Grobusch MP: Placental malaria increases malaria risk in the first 30 months of life. Clin Infect Dis 2008, 47:1017-1025.

16. Malhotra I, Dent A, Mungai P, Wamachi A, Ouma JH, Narum DL, Muchiri E, Tisch DJ, King CL: Can prenatal malaria exposure produce an immune tolerant phenotype? A prospective birth cohort study in Kenya. PLoS Med 2009, 6:e1000116.

17. Le Port A, Watier L, Cottrell G, Oue S, Pierrat C, Rachas A, Bouscaillou J, Bouraima A, Massougbodji A, Chandre F, Migot-nabias F, Fayomi B, Thie A, Cot M: Infections in infants during the first 12 months of life: role of placental malaria and environmental factors. PLoS One 2011, 6:e27516.

18. Tonga C, Kimbi HK, Anchang-Kimbi JK, Nyabeyeu HN, Bissemou ZB, Lehman LG: Malaria risk factors in women on intermittent preventive treatment at delivery and their effects on pregnancy outcome in Sanaga-Maritime, Cameroon. PLoS One 2013, 8:e65876.

19. World Health Organization: World Malaria Report 2013. Geneva: WHO Publ; 2013.

20. Rachas A, Le Port A, Cottrell G, Guerra J, Choudat I, Bouscaillou J, Massougbodji A, Garcia A: Placental malaria is associated with increased risk of nonmalaria infection during the first 18 months of life in a Beninese population. Clin Infect Dis 2012, 55:672-678.

21. Slutsker L, Khoromana CO, Hightower AW, Macheso A, Wirima JJ, Breman $J G$, Heymann DL, Steketee RW: Malaria infection in infancy in rural Malawi. Am J Trop Med Hyg 1996, 55:71-76.

22. Bardaji A, Sigauque B, Sanz S, Maixenchs M, Ordi J, Aponte JJ, Mabunda S, Alonso PL, Menéndez C: Impact of malaria at the end of pregnancy on infant mortality and morbidity. J Infect Dis 2011, 203:691-699.

23. Le Port A, Cottrell G, Martin-Prevel Y, Migot-nabias F, Cot M: First malaria infections in a cohort of infants in Benin: biological, environmental and genetic determinants: description of the study site, population methods and preliminary results. BMJ Open 2012, 2:e000342.

24. Borgella S, Fievet N, Huynh B-T, Ibitokou S, Hounguevou G, Affedjou J, Sagbo J-C, Houngbegnon P, Guezo-Mévo B, Massougbodji A, Luty AJF, Cot $M$, Deloron P: Impact of pregnancy-associated malaria on infant malaria infection in southern Benin. PLoS One 2013, 8:e80624.
25. Falade C, Mokuolu O, Okafor H, Orogade A, Falade A, Adedoyin O, Oguonu T, Aisha M, Hamer DH, Callahan MV: Epidemiology of congenital malaria in Nigeria: a multi-centre study. Trop Med Int Health 2007, 12:1279-1287.

26. Vanga-Bosson H, Coffie P, Kanhon S, Sloan C, Kouakou F, Eholie SP, Kone M, Dabis F, Menan H, Ekouevi DK: Coverage of intermittent prevention treatment with sulphadoxine-pyrimethamine among pregnant women and congenital malaria in Côte d'Ivoire. Malar J 2011, 10:105.

27. Omalu ICJ, Mgbemena C, Mgbemena A, Ayanwale V, Olayemi IK, Lateef A, Chukwuemeka VI: Prevalence of congenital malaria in Minna, north central Nigeria. J Trop Med 2012, 2012:274142.

28. Ouédraogo A, Tiono AB, Diarra A, Bougouma ECC, Nébié I, Konaté AT, Sirima SB: Transplacental transmission of Plasmodium falciparum in a highly malaria endemic area of Burkina Faso. J Trop Med 2012 2012:109705.

29. Enweronu-Laryea CC, Adjei GO, Mensah B, Duah N, Quashie NB: Prevalence of congenital malaria in high-risk Ghanaian newborns: a cross-sectional study. Malar J 2013, 12:17.

30. Menendez C, Mayor A: Congenital malaria: the least known consequence of malaria in pregnancy. Semin Fetal Neonatal Med 2007, 12:207-213.

31. Ibhanesebhor SE: Clinical characteristics of neonatal malaria. J Trop Pediatr 1995, 41:330-333.

32. Dechavanne C, Pierrat C, Renard E, Costes B, Martin N, Ladekpo R, Ahouangninou C, Moya Alvarez V, Huyn BT, Garcia A, Migot-Nabias F: Genetic characterization of Plasmodium falciparum allelic variants infecting mothers at delivery and their children during their first plasmodial infections. Infect Genet Evol 2013, 20:16-25.

33. Branch $\mathrm{OH}$, Udhayakumar $\mathrm{V}$, Hightower AW, Oloo AJ, Hawley WA, Nahlen BL, Bloland PB, Kaslow DC, Lal AA: A longitudinal investigation of IgG and $\operatorname{lgM}$ antibody responses to the merozoite surface protein-1 19-kiloDalton domain of Plasmodium falciparum in pregnant women and infants: associations with febrile illness, parasitemia, and anemia. Am J Trop Med Hyg 1998, 58:211-219.

34. Okoko BJ, Wesumperuma LH, Ota MO, Pinder M, Banya W, Gomez SF, McAdam KP, Hart AC: The influence of placental malaria infection and maternal hypergammaglobulinemia on transplacental transfer of antibodies and IgG subclasses in a rural West African population. I Infect Dis 2001, 184:627-632.

35. Riley EM, Wagner GE, Akanmori BD, Koram KA: Do maternally acquired antibodies protect infants from malaria infection? Parasite Immunol 2001, 23:51-59.

36. Brabin BJ: An analysis of malaria in pregnancy in Africa. Bull World Health Organ 1983, 61:1005-1016.

37. Verhoeff FH, Le Cessie S, Kalanda BF, Kazembe PN, Broadhead RL, Brabin BJ: Post-neonatal infant mortality in Malawi: the importance of maternal health. Ann Trop Paediatr 2004, 24:161-169.

38. Garcia A, Milet J, Courtin D, Sabbagh A, Massaro JD, Castelli EC, MigotNabias F, Favier B, Rouas-Freiss N, Donadi EA, Moreau P: Association of HLA-G 3'UTR polymorphisms with response to malaria infection: a first insight. Infect Genet Evol 2013, 16:263-269.

39. Abu-Raddad L, Patnaik P, Kublin JG: Dual infection with HIV and malaria fuels the spread of both diseases in sub-Saharan Africa. Science 2006, 314:1603-1606.

40. Ladner J, Leroy V, Karita E, Van de Perre P, Dabis F: Malaria, HIV and pregnancy. AIDS 2003, 17:275-276.

41. Bulterys PL, Chao A, Dalai SC, Zink MC, Dushimimana A, Katzenstein D, Saah AJ, Bulterys M: Placental malaria and mother-to-child transmission of human immunodeficiency virus-1 in rural Rwanda. Am J Trop Med Hyg 2011, 85:202-206.

42. Kourtis AP, Lee FK: Understanding the timing of HIV. JAMA 2014, 285(6):18-21.

43. Perrault SD, Hajek J, Zhong K, Owino SO, Sichangi M, Smith G, Shi YP, Moore JM, Kain KC: Human immunodeficiency virus co-infection increases placental parasite density and transplacental malaria transmission in Western Kenya. Am J Trop Med Hyg 2009, 80:119-125.

44. Van Eijk AM, Ayisi JG, ter Kuile FO, Misore AO, Otieno JA, Rosen DH, Kager PA, Steketee RW, Nahlen BL: HIV increases the risk of malaria in women of all gravidities in Kisumu, Kenya. AIDS 2003, 17:595-603.

45. Menendez C, Ordi J, Ismail MR, Ventura PJ, Aponte JJ, Kahigwa E, Font F, Alonso PL: The impact of placental malaria on gestational age and birth weight. J Infect Dis 2000, 181:1740-1745. 
46. Guyatt HL, Snow RW: Impact of malaria during pregnancy on low birth weight in sub-Saharan Africa. Clin Microbiol Rev 2004, 17:760-769.

47. Steketee RW: Malaria prevention in pregnancy: when will the prevention programme respond to the science. J Health Popul Nutr 2002, 20:1-3.

48. McDonald CR, Elphinstone RE, Kain KC: The impact of placental malaria on neurodevelopment of exposed infants: a role for the complement system? Trends Parasitol 2013, 29:213-219.

49. Ismaili J, van der Sande M, Holland MJ, Sambou I, Keita S, Allsopp C, Ota MO, Mcadam KPWJ: Plasmodium falciparum infection of the placenta affects newborn. Clin Exp Immunol 2003, 133:414-421.

50. Huynh B-T, Fievet N, Gbaguidi G, Dechavanne S, Borgella S, Guézo-Mévo B, Massougbodji A, Ndam NT, Deloron P, Cot M: Influence of the timing of malaria infection during pregnancy on birth weight and on maternal anemia in Benin. Am J Trop Med Hyg 2011, 85:214-220.

51. Bardají A, Bassat $\mathrm{Q}$, Alonso PL, Menéndez C: Intermittent preventive treatment of malaria in pregnant women and infants: making best use of the available evidence. Expert Opin Pharmacother 2012, 13:1719-1736.

52. Valea I, Tinto H, Drabo MK, Huybregts L, Sorgho H, Ouedraogo J, Guiguemde RT, Van Geertruyden JP, Kolsteren P, Alessandro UD, Misame FSP: An analysis of timing and frequency of malaria infection during pregnancy in relation to the risk of low birth weight, anaemia and perinatal mortality in Burkina Faso. Malar J 2012, 11:71.

53. Kalilani-Phiri L, Thesing PC, Nyirenda OM, Mawindo P, Madanitsa M, Membe G, Wylie B, Masonbrink A, Makwakwa K, Kamiza S, Muehlenbachs A, Taylor TE, Laufer MK: Timing of malaria infection during pregnancy has characteristic maternal, infant and placental outcomes. PLOS One 2013, 8:e74643.

54. Kayentao K, Garner P, van Eijk AM, Naidoo I, Mulokozi A, Macarthur JR, Luntamo M, Ashorn P, Doumbo OK, ter Kuile FO: Intermittent preventive therapy for malaria during pregnancy using 2 vs 3 or more doses of sulfadoxine-pyrimethamine and risk of low birth weight in Africa. JAMA 2013, 309:594-604

55. WHO Malaria Policy Advisory Committee and Secretariat: Malaria Policy Advisory Committee to the WHO: conclusions and recommendations of September 2013 meeting. Malar J 2013, 12:456.

56. Ter Kuile FO, van Eijk AM, Filler SJ: Resistance on the efficacy of intermittent preventive therapy. J Am Med Assoc 2007, 297:2603-2616.

57. Menéndez C, Bardají A, Sigauque B, Romagosa C, Sanz S, Serra-Casas E, Macete E, Berenguera A, David C, Dobaño C, Naniche D, Mayor A, Ordi J, Mandomando I, Aponte JJ, Mabunda S, Alonso PL: A randomized placebo-controlled trial of intermittent preventive treatment in pregnant women in the context of insecticide treated nets delivered through the antenatal clinic. PLoS One 2008, 3:e1934.

58. Kayentao K, Kodio M, Newman RD, Maiga H, Doumtabe D, Ongoiba A, Coulibaly D, Keita AS, Maiga B, Mungai M, Parise ME, Doumbo O: Comparison of intermittent preventive treatment with chemoprophylaxis for the prevention of malaria during pregnancy in Mali. J Infect Dis 2005, 191:109-116.

59. Schultz LJ, Steketee RW, Macheso A, Kazembe P, Chitsulo L, Wirima JJ: The efficacy of antimalarial regimens containing sulfadoxine-pyrimethamine and/or chloroquine in preventing peripheral and placental Plasmodium falciparum infection among pregnant women in Malawi. Am J Trop Med Hyg 1994, 51:515-522.

60. McClure EM, Goldenberg RL, Dent AE, Meshnick SR: A systematic review of the impact of malaria prevention in pregnancy on low birth weight and maternal anemia. Int J Gynaecol Obstet 2013, 121:103-109.

61. Diakite OSM, Maiga OM, Kayentao K, Traoré BT, Djimde A, Traoré B, Diallo M, Traoré M, Ongoiba A, Doumtabé D, Doumbo S, Traoré MS, Dara A, Guindo O, Karim DM, Coulibaly S, Bougoudogo F, Ter Kuile FO, Danis M, Doumbo OK: Superiority of 3 over 2 doses of intermittent preventive treatment with sulfadoxine-pyrimethamine for the prevention of malaria during pregnancy in mali: a randomized controlled trial. Clin Infect Dis 2011, 53:215-223.

62. Briand V, Bottero J, Noël H, Masse V, Cordel H, Guerra J, Kossou H, Fayomi B, Ayemonna P, Fievet N, Massougbodji A, Cot M: Intermittent treatment for the prevention of malaria during pregnancy in Benin: a randomized, open-label equivalence trial comparing sulfadoxine-pyrimethamine with mefloquine. J Infect Dis 2009, 200:991-1001.

63. Gutman J, Mwandama D, Wiegand RE, Ali D, Mathanga DP, Skarbinski J: Effectiveness of intermittent preventive treatment with sulfadoxine- pyrimethamine during pregnancy on maternal and birth outcomes in Machinga district, Malawi. J Infect Dis 2013, 208:907-916.

64. Harrington WE, Mutabingwa TK, Kabyemela E, Fried M, Duffy PE: Intermittent treatment to prevent pregnancy malaria does not confer benefit in an area of widespread drug resistance. Clin Infect Dis 2011, 53:224-230.

65. Harrington WE, Morrison R, Fried M, Duffy PE: Intermittent preventive treatment in pregnant women is associated with increased risk of severe malaria in their offspring. PLoS One 2013, 8:e56183.

66. Taylor SM, Antonia AL, Chaluluka E, Mwapasa V, Feng G, Molyneux ME, ter Kuile FO, Meshnick SR, Rogerson SJ: Antenatal receipt of sulfadoxinepyrimethamine does not exacerbate pregnancy-associated malaria despite the expansion of drug-resistant Plasmodium falciparum: clinical outcomes from the QuEERPAM study. Clin Infect Dis 2012, 55:42-50.

67. Tagbor H, Bruce J, Agbo M, Greenwood B, Chandramohan D: Intermittent screening and treatment versus intermittent preventive treatment of malaria in pregnancy: a randomised controlled non-inferiority trial. PLoS One 2010, 5:e14425.

68. Taylor SM, Antonia AL, Mwapasa V, Feng G, Molyneux ME, ter Kuile FO, Meshnick SR, Rogerson SJ: Reply to Harrington et al. Clin Infect Dis 2012, 55:1026-1027.

\section{doi:10.1186/1475-2875-13-271}

Cite this article as: Moya-Alvarez et al.: Pregnancy-associated malaria and malaria in infants: an old problem with present consequences. Malaria Journal 2014 13:271.

\section{Submit your next manuscript to BioMed Central and take full advantage of:}

- Convenient online submission

- Thorough peer review

- No space constraints or color figure charges

- Immediate publication on acceptance

- Inclusion in PubMed, CAS, Scopus and Google Scholar

- Research which is freely available for redistribution

Submit your manuscript at www.biomedcentral.com/submit
C Biomed Central 